\title{
Study on the Enhanced Operation of Self-Ventilation-Based Coupling System for Domestic Wastewater Treatment
}

\author{
Lingwei Kong ${ }^{1}$, Lu Wang ${ }^{3}$, Yi Zhang ${ }^{2}$, Rongwu $\mathrm{Mei}^{1}$, and Yu Zhang ${ }^{1}$ \\ ${ }^{1}$ Environmental Science Research and Design Institute of Zhejiang Province, Hangzhou 310007; \\ ${ }^{2}$ Institute of Hydrobiology, Chinese Academy of Sciences, Wuhan, 430072; \\ ${ }^{3}$ Zhejiang Greentown LEAP Architecture Design Consulting Company, Hangzhou, 310005
}

\begin{abstract}
In this study, a new coupling system of biological filter bed and subsurface-flow constructed wetland based on the self-ventilation network was proposed, and the comparative pollutant removal efficiency at low and high influent concentration of the pilot coupling system with different substrates configurations were investigated. The study found that: The comparison system (b) had better removal rates than that of the original system (a), and the removal rate when treating low influent concentration was $74.10 \%, 94.14 \%, 73.57 \%$ and $69.53 \%$, while in high influent concentration case was $81.30 \%, 90.28 \%$, $88.57 \%$ and $75.36 \%$ for $\mathrm{COD}_{\mathrm{Cr}}, \mathrm{NH}_{4}{ }^{+}-\mathrm{N}$, TN and $\mathrm{TP}$, respectively. The removal of the above main water indexes of the comparison system (b) promoted by $11.00 \%, 11.55 \%, 2.69 \%$ and $8.09 \%$ respectively in low influent concentration case and $4.20 \%, 9.20 \%, 7.66 \%$ and $13.61 \%$ respectively in high influent concentration case when comparing to the original system (a), which showed that the optimized configuration of various kinds of substrates was significant and was more beneficial to the degradation and removal of pollutants. The adsorption and interception function of substrates in the constructed wetland was the main way of phosphorus removal. The function of self-ventilation ensured the amount of DO in the coupling system, making the phosphorus removal was less affected comparing to structure of traditional wetland.
\end{abstract}

\section{Introduction}

Different treatment process has different effects on wastewater treatment, which will have a directly impact on the environment $[1,2]$. The main method of rural sewage treatment in Japan is membrane process submerged in a small domestic sewage purification device, which has the merit of small aera demand, low cost, simple operation etc..; The Filter process used in Australia for rural domestic wastewater treatment is a combination wastewater reuse system of filtration, land treatment and culvert drainage [3]; In South Korea, soil filtration-plant system is used for rural sewage treatment, and after purification the effluent is used for farmland irrigation [4]. For rural domestic sewage treatment is mainly a single process, in recent years, some scholars have found their own ways and develop more practical combined treatment processes, such as the combination process of anaerobic biological filter and constructed wetland [5], bio-ecological combination system [6] and biological contact oxidation process-constructed wetland technology [7].

The rural domestic sewage has the characteristics of complex composition, high nitrogen and phosphorus, thus the single-stage constructed wetland cannot effectively degrade nitrogen and phosphorus in the actual treatment process. In this study, we used a new self-ventilation network biological filter bed and subsurface-flow constructed wetland coupling process, and selected different substrates and gradation to carry out the pilot construction to investigate the actual operation effect and influence factors, accumulating engineering experiences and design parameters for the further demonstration project.

\section{Experimental materials and methods}

\subsection{Experimental materials and process options}

The pilot project is to treat domestic sewage collected from Zhong village, which locates in Qiushi village, Jingshan town, Yuhang district, Hangzhou city, Zhejiang province. The new self-ventilation networking biological filter bed and subsurface-flow constructed wetland coupling process was made up of the upper layered biological filter bed and lower layered subsurface-flow constructed wetland. The flow chart and the scene of pilot-scale project is shown in Fig.2-1 and Fig.2-2, respectively:

\footnotetext{
* Corresponding author:77378154@qq.com, 50991460@qq.com, zhangyi@ihb.ac.cn, mrw0518@sina.com, zhangyu0103@126.com,
} 


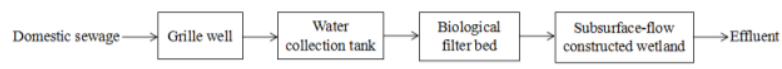

Fig.2-1. The flow chart of the pilot project of the biological filter and subsurface-flow constructed wetland coupling

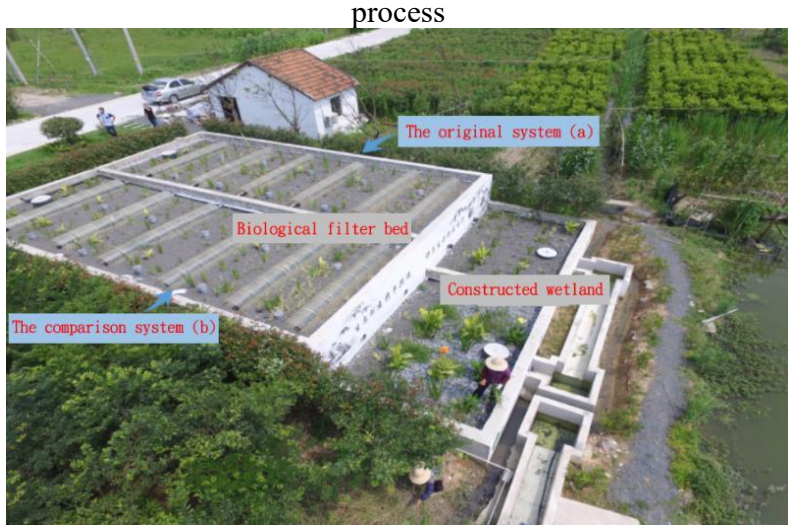

Fig.2-2. The scene of pilot-scale project in Yuhang district of Hangzhou.

Under the same conditions of influent, ventilation and plant selection, the pilot project selected different types of substrates and gradation, designed two parallel coupling systems to investigate the effects of different substrates and configuration on the removal of pollutants, finally get a set of optimal operating parameters. As shown in Fig. 2-2, two sets of biological filter beds and subsurface-flow constructed wetland coupling system are separated by partitions, the right side is the original system (a) with blended filter stone, and on the other side is the comparison system (b) with different substrates. As can be seen from Fig. 2-2 that the upper layer is a biological filter bed, the lower layer is a subsurface-flow constructed wetland, and the left part of the subsurface-flow constructed wetland is covered by the biological filter bed unit of the same area in the upper layer, forming a local overlapping superposition.

The specific design parameters of pilot project are as follows: Grille well: $1.00 \mathrm{~m} \times 1.00 \mathrm{~m} \times 1.50 \mathrm{~m}$, steel mixed (buried); Regulating pond: $2.50 \mathrm{~m} \times 4.80 \mathrm{~m} \times 3.00 \mathrm{~m}$, steel mixed (buried), there format structure, similar to the role of septic tank hydrolysis acidification pool; Biological filter bed: $109.20 \mathrm{~m}^{2}$, high: $1.20 \mathrm{~m}$, concrete cofferdam, geomembrane seepage control, placed above the subsurface-flow constructed wetlands; Biological filter substrates: $120 \mathrm{~m}^{3}$, plantation of iris and ryegrass with a density of $30 \mathrm{plies} / \mathrm{m}^{2}$; Subsurface-flow constructed wetland: $140.20 \mathrm{~m}^{2}$, high: $1.50 \mathrm{~m}$, concrete cofferdam, geomembrane seepage control; Wetland filters: $225 \mathrm{~m}^{3}$, planting canna in subsurface-flow wetland without being covered by biological filter bed, the density of 9 plants $/ \mathrm{m}^{2}$; Out of the well: brick: $0.60 \mathrm{~m} \times 0.60 \mathrm{~m} \times 0.70$ $\mathrm{m}$.

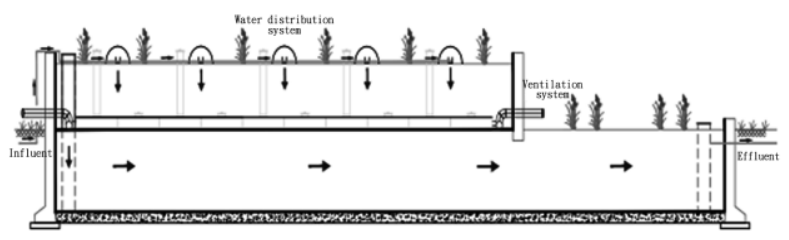

Fig.2-3. Structure and flow pattern of pilot project
Fig. 2-3 is a schematic diagram of the specific structure of the pilot project, coupled with the process of influent, effluent and the flow direction of sewage in the system. As shown in Fig. 2-3, the sewage is pretreated by the grating and the regulating pond, then lifted to the biological filter bed unit. The sewage is uniformly distributed through the water distribution pipe groove installed on the surface of the biological filter bed filter layer. Treated sewage at the bottom of the biological filter bed along the slope to the left of the water gathering well, and then through the water gathering well installed in the subsurface-flow constructed wetland water distribution system, making the sewage from left to right through the design of different filters area after filtration treatment effluent.

The original system (a) substrates composition: 1) The biological filter bed unit selected the filter stone with calcium (limestone, etc.). Vertical laying on three floors, Upper $(\mathrm{H}=700 \mathrm{~mm}, \phi=2-5 \mathrm{~mm})$, middle $(\mathrm{H}=$ $100 \mathrm{~mm}, \phi=13 \mathrm{~mm})$, the lower layer $(\mathrm{H}=400 \mathrm{~mm}, \phi=$ $25 \mathrm{~mm})$; 2) Subsurface-flow constructed wetland units selected the filter stone with calcium (limestone, etc.); From left to right laying length and size specifications were $(\mathrm{L}=2500 \mathrm{~mm}, \phi=40 \mathrm{~mm}),(\mathrm{L}=1600 \mathrm{~mm}, \phi=25$ $\mathrm{mm}),(\mathrm{L}=1600 \mathrm{~mm}, \phi=13 \mathrm{~mm}),(\mathrm{L}=5600 \mathrm{~mm}, \phi=2-5$ $\mathrm{mm})$. In addition, two groups of horizontal and vertical blocks laid at the end of the subsurface-flow constructed wetlands are $\mathrm{L}=1600 \mathrm{~mm}\left(\mathrm{H}_{\text {upper }}=200 \mathrm{~mm}, \phi=2-5\right.$ $\left.\mathrm{mm} ; \mathrm{H}_{\text {lower layer }}=1300 \mathrm{~mm}, \phi=13 \mathrm{~mm}\right)$ and $\mathrm{L}=2500$ $\mathrm{mm}\left(\mathrm{H}_{\text {upper }}=200 \mathrm{~mm}, \phi=2-5 \mathrm{~mm} ; \mathrm{H}_{\text {middle }}=100 \mathrm{~mm}, \phi\right.$ $=13 \mathrm{~mm} ; \mathrm{H}_{\text {lower layer }}=1200 \mathrm{~mm}, \phi=25 \mathrm{~mm}$ ).

The comparison system (b) substrates composition: 1) The biological filter bed unit selected three types of material of melon gravel, zeolite, ceramsite, vertical laying on three floors, Upper (melon broken gravel, $\mathrm{H}=$ $700 \mathrm{~mm}, \phi=3-5$ ), middle (zeolite, $\mathrm{H}=100 \mathrm{~mm}, \phi=10$ $-15 \mathrm{~mm}$ ), the lower layer (ceramsite, $\mathrm{H}=400 \mathrm{~mm}, \phi=$ 20-40 mm) ; 2) Subsurface-flow constructed wetland units selected the filter stone with calcium; From left to right laying length and size specifications were (ceramsite, $\mathrm{L}=2500 \mathrm{~mm}, \phi=20-40 \mathrm{~mm}$ ), (zeolite, $\mathrm{L}=$ $1600 \mathrm{~mm}, \phi=10-15 \mathrm{~mm}$ ), (Melon-gravel, $\mathrm{L}=7200 \mathrm{~mm}$, $\phi=3-5 \mathrm{~mm}$ ). In addition, two groups of horizontal and vertical blocks laid at the end of the subsurface-flow constructed wetlands are $\mathrm{L}=1600 \mathrm{~mm}$ (Melon-gravel, $\mathrm{H}$ upper $=200 \mathrm{~mm}, \phi=3-5 \mathrm{~mm}$; zeolite, $\mathrm{H}_{\text {lower layer }}=1300$ $\mathrm{mm}, \phi=10-15 \mathrm{~mm}$ ) and $\mathrm{L}=2500 \mathrm{~mm}$ (Melon-gravel, $\mathrm{H}$ upper $=200 \mathrm{~mm}, \phi=3-5 \mathrm{~mm}$; zeolite, $\mathrm{H}_{\text {middle }}=100 \mathrm{~mm}, \phi$ $=10-15 \mathrm{~mm}$; ceramsite, $\mathrm{H}$ lower layer $=1200 \mathrm{~mm}, \phi=20-40$ $\mathrm{mm})$.

\subsection{Process parameters}

The influent volume of pilot project design is $50 \mathrm{~m}^{3} / \mathrm{d}$, the two sets of coupling system for the operation of a comparative study from May of 2016 to December of 2016 for a period of low concentration and June of 2017 to September of 2017 for a series of high concentration influent period. In the stable operation stage, the influent parameters of pilot project of the new biological filter 
bed and subsurface-flow constructed wetland coupling system are shown in table 2-1.

Table 2-1 Influent quality indicators (Unit: mg/L)

\begin{tabular}{ccc}
\hline $\begin{array}{c}\text { Water quality } \\
\text { indicators }\end{array}$ & $\begin{array}{c}\text { Low } \\
\text { concentration }\end{array}$ & $\begin{array}{c}\text { High } \\
\text { concentration }\end{array}$ \\
\hline $\mathrm{COD}_{\mathrm{Cr}}$ & $7.87 \sim 45.60$ & $24.00 \sim 442.00$ \\
$\mathrm{NH}_{4}{ }^{+}-\mathrm{N}$ & $4.72 \sim 34.40$ & $11.10 \sim 58.00$ \\
$\mathrm{TN}$ & $7.59 \sim 35.50$ & $16.70 \sim 73.60$ \\
$\mathrm{TP}$ & $1.24 \sim 3.44$ & $1.82 \sim 6.98$ \\
\hline
\end{tabular}

The new biological filter bed system and the subsurface-flow constructed wetland system are operated in intermittent ways, and the biological filter bed has a HRT of $18.87 \mathrm{~h}$ while for the subsurface-flow constructed wetland system is $57.54 \mathrm{~h}$.

\subsection{Analysis of projects, sampling and testing methods}

The test indexs mainly including $\mathrm{COD}_{\mathrm{Cr}}, \mathrm{TN}, \mathrm{NH}_{4}{ }^{+}-\mathrm{N}$ and TP. Measurement items and methods are shown in table 2-2.

Table 2-2 Test indicators and methods of the experiment

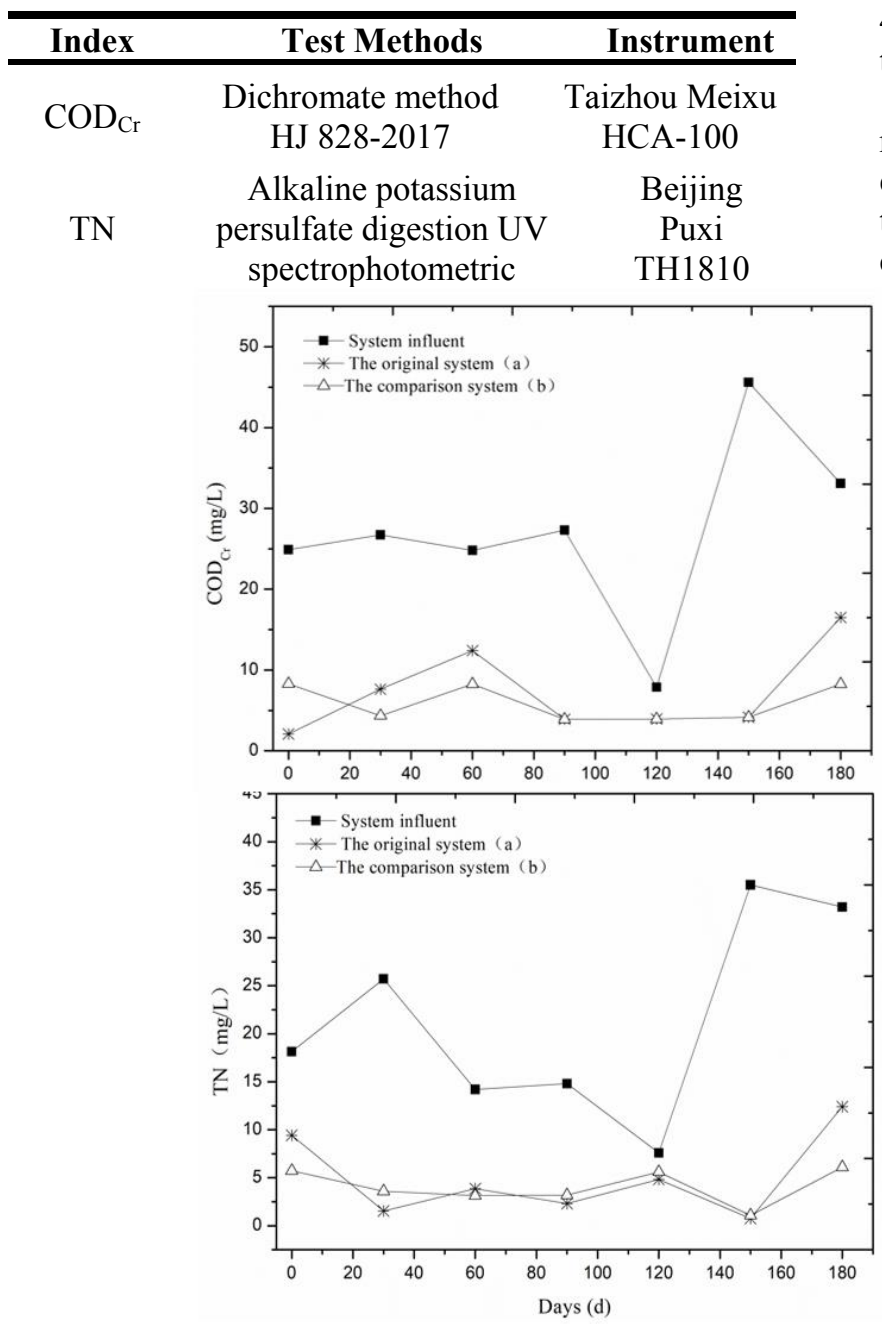

method HJ 636-2012

Nessler' reagent

$\mathrm{HN}_{4}{ }^{+}-\mathrm{N} \quad$ spectrophotometric Beijing

HJ 535-2009

Puxi T6

Ammonium molybdate

spectrophotometric method GB/T 11893-1989

Beijing

Puxi T6

\section{Results and discussion}

\subsection{Study on the pollutant removal of pilot project coupling system with different substrates configurations at low influent concentration}

Different natural conditions, water habits and the level of economic development can lead to the differences in the water quality of rural sewage. Some scholars [8] in their study of ecological filter bed technology of rural domestic sewage in the west mountainous area of Zhejiang found that the influent concentration of main water quality indicators like $\mathrm{COD}_{\mathrm{Cr}}, \mathrm{NH}_{4}{ }^{+}-\mathrm{N}, \mathrm{TN}$ and TP was $32.10 \mathrm{mg} / \mathrm{L}, 1.13 \mathrm{mg} / \mathrm{L}, 1.33 \mathrm{mg} / \mathrm{L}$ and $0.61 \mathrm{mg} / \mathrm{L}$ respectively, and operation results showed that the above indexes of removal rate reached to $43.30 \%, 56.42 \%$, $42.11 \%$ and $19.88 \%$ respectively, which even lower than the micro-polluted surface water [9].

Fig.3-1 shows the $\mathrm{COD}_{\mathrm{Cr}}, \mathrm{NH}_{4}{ }^{+}-\mathrm{N}, \mathrm{TN}$ and $\mathrm{TP}$ removal performance of two coupled systems. The effluent of the system (a) and the system effluent (b) are the effluent from the original system (a) and the comparison system (b), respectively.

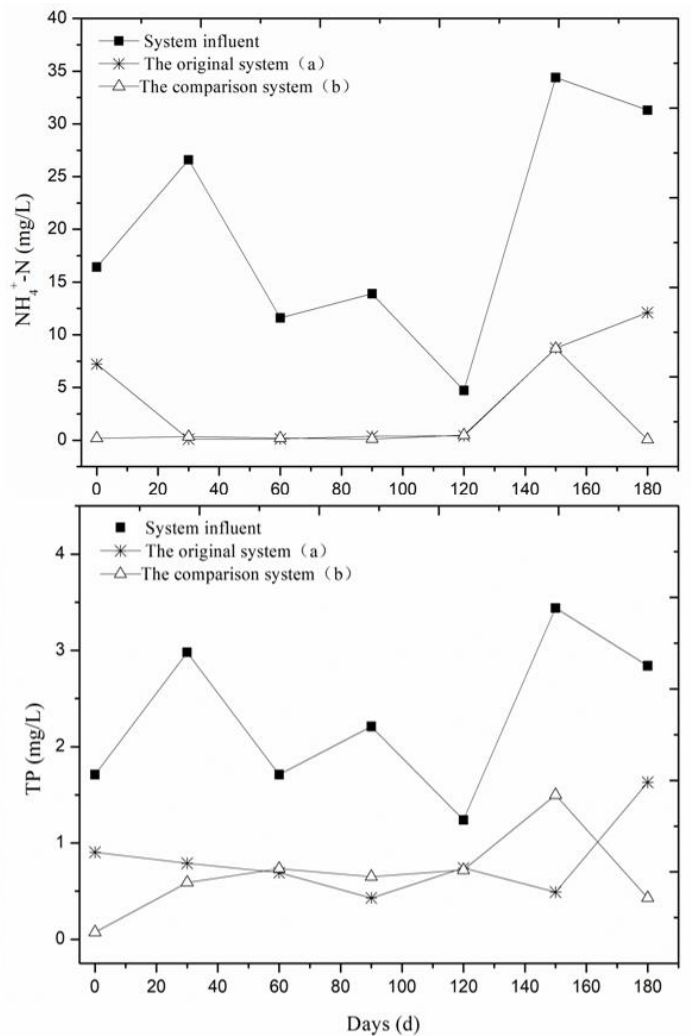

Fig.3-1 Removal of low influent concentration of $\mathrm{COD}_{\mathrm{Cr}} 、 \mathrm{NH}_{4}{ }^{+}-\mathrm{N} 、 \mathrm{TN}$ and $\mathrm{TP}$ by coupling system 
As can be seen from Fig.3-1, the concentration of effluent $\mathrm{COD}_{\mathrm{Cr}}$ has been cut down to a certain degree after the pretreatment of grille and adjust pool, however, there has been a great change. It can also be seen from the figure that the influent of the coupling system is irregular, and the influent concentration comes to the lowest and the highest at 120th and 150th days respectively. The original system (a) and the comparison system (b) both maintain relatively satisfactory removal efficiency despite the relatively large fluctuations in water influent, of which the total average effluent $\mathrm{COD}_{\mathrm{Cr}}$ concentration reaches to $7.23 \mathrm{mg} / \mathrm{L}$ and $5.88 \mathrm{mg} / \mathrm{L}$ while the removal rate is $63.10 \%$ and $74.10 \%$ respectively.

Although the $\mathrm{NH}_{4}{ }^{+}-\mathrm{N}$ concentration of the system fluctuates in a certain range, the original system (a) and the comparison system (b) reaches to $4.16 \mathrm{mg} / \mathrm{L}$ and $1.45 \mathrm{mg} / \mathrm{L}$, respectively, and both maintain a good overall removal effect. The comparison system (b) has better effluent effect and the removal rate is $94.14 \%$. The sampling of the effluent $\mathrm{NH}_{4}{ }^{+}-\mathrm{N}$ concentration of the original system (a) and the comparison system (b) are the same in the $30 \mathrm{~d} \sim 90 \mathrm{~d}$, and at the end of the sampling the $\mathrm{NH}_{4}{ }^{+}-\mathrm{N}$ concentration of the comparison system (b) is lower than that of original system (a).

The variation trend of TN concentration in the pilot coupling system is similar to that of $\mathrm{NH}_{4}{ }^{+}-\mathrm{N}$, and both the effluent $\mathrm{NH}_{4}{ }^{+}-\mathrm{N}$ concentration of the original system (a) and the comparison system (b) basically keep decreasing from the initial to the 150th day, then both of the effluent concentrations begin to increase as the temperature decreases. The average effluent concentration of the original system (a) and the comparison system (b) reaches to $5.02 \mathrm{mg} / \mathrm{L}$ and 4.06 $\mathrm{mg} / \mathrm{L}$ respectively, and in accordingly the TN removal rate reaches to $70.88 \%$ and $73.57 \%$ respectively, maintaining a good overall removal effect.

It is also known from Fig.3-1 that the fluctuation range of the influent TP concentration is larger (1.24 $\mathrm{mg} / \mathrm{L} \sim 3.44 \mathrm{mg} / \mathrm{L}$ ), and there is no obvious change in the variation. The effluent TP concentration of the original system (a) has a slightly decrease trend in the beginning $150 \mathrm{~d}$, and the effluent TP concentration increases to 1.63 $\mathrm{mg} / \mathrm{L}$ according to the decrease of temperature that after, which may be related to absorption ability of the calcium-contained substrate in the original system (a); The effluent TP concentration of the comparison system (b) shows a rising trend at the early stage and reaches to highest at $150 \mathrm{~d}$, then decreases, and has an average removal rate of $69.53 \%$.

\subsection{Study on the pollutant removal of pilot project coupling system with different substrates configurations at high influent concentration}

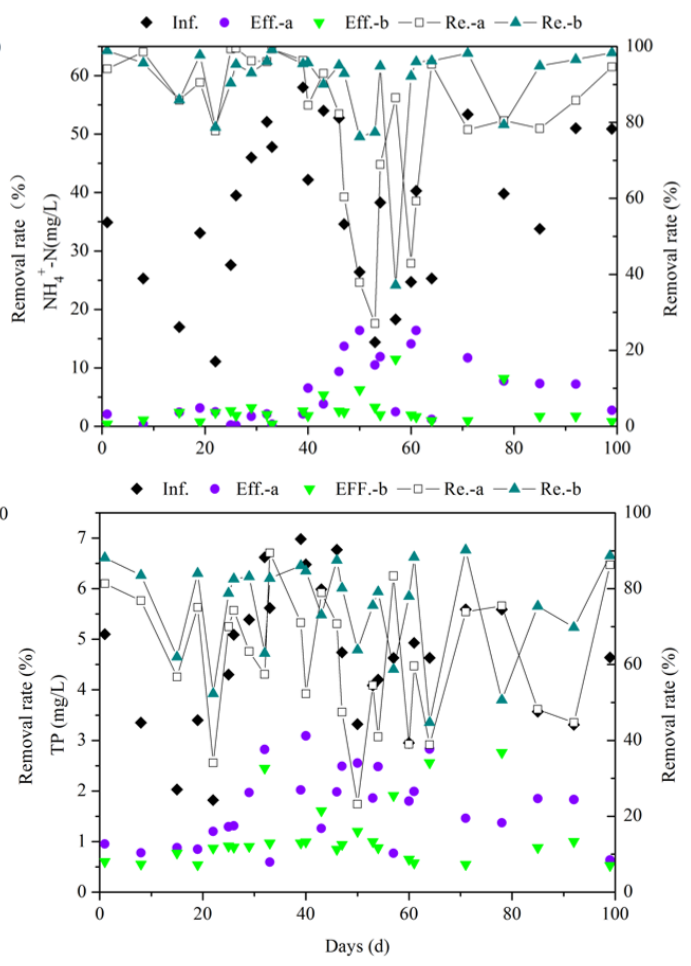

$\mathrm{COD}_{\mathrm{Cr}} 、 \mathrm{NH}_{4}^{+}-\mathrm{N} 、 \mathrm{TN}$ and TP by coupling system maintained an efficient removal effect, the average $\mathrm{COD}_{\mathrm{Cr}}$ concentrations of the total effluent reached 23.63 $\mathrm{mg} / \mathrm{L}$ and $20.22 \mathrm{mg} / \mathrm{L}$, the removal rates were $77.10 \%$ and $81.30 \%$ respectively. $\mathrm{COD}_{\mathrm{Cr}}$ removal rate of the comparison system (b) is more stable than the original system (a), and the average removal rate is better than the original system (a). Vymazal [10] studied the $\mathrm{COD}_{\mathrm{Cr}}$ 
removal efficiencies of horizontal-vertical wetland and multi-stage composite constructed wetlands, which were $84.00 \%$ and $83.80 \%$ respectively, similar to the study.

Fig.3-2 reflects the contribution of the coupling system to the removal of $\mathrm{NH}_{4}{ }^{+}-\mathrm{N}$. As can be seen from the figure, although the influent concentration of $\mathrm{NH}_{4}{ }^{+}-\mathrm{N}$ fluctuated within a certain range, the average effluent concentrations of the original system (a) and the comparison system (b) reached $5.93 \mathrm{mg} / \mathrm{L}$ and 2.70 $\mathrm{mg} / \mathrm{L}$ respectively, both of which remained better overall removal effect. Compared with the two, the comparison system (b) has better effluent effect and the removal rate is $90.28 \%$.

The original system (a) had the lowest removal rate of $\mathrm{NH}_{4}{ }^{+}-\mathrm{N}$ on the $53 \mathrm{rd}$ day, only $27.08 \%$, and its corresponding influent concentration was also lower at $14.40 \mathrm{mg} / \mathrm{L}$. The comparatively high removal rate of the comparison system (b) shows that the removal efficiency of constructed wetlands with a variety of substrates configurations are less affected by the influent pollution load, own to the synergistic effect among various substrates [11]. Some research results [12-16] show that the removal rates of $\mathrm{NH}_{4}{ }^{+}-\mathrm{N}$ and $\mathrm{TN}$ are $57 \% \sim 71 \%$ and $50 \% \sim 75 \%$ in composite constructed wetland, respectively. Relative to the original system (a), the removal effect is relatively stable but the average removal rate is lower, the removal rate of the original system (a) is not stable may be related to the single configuration of the substrates.

The removal mechanism of $\mathrm{N}$ by constructed wetlands is very complicated [17], mainly including ammonia volatilization, matrix adsorption, plant absorption and microbial nitrification/denitrification. The main role is nitrification/denitrification [18,19], plant absorption from the long-term results to see only the second. As can be seen in Fig. 3-4, the average TN concentration of the effluent from the original system (a) and the comparison system (b) reached $7.27 \mathrm{mg} / \mathrm{L}$ and $4.40 \mathrm{mg} / \mathrm{L}$, respectively, meeting A level in the standard of 《Discharge standard of pollutants for municipal wastewater treatment plant》(GB 18918-2002), the original system (a) and the comparison system (b) on the TN removal rate reached $80.91 \%$ and $88.57 \%$. Chen [20] selected anaerobic contact oxidation pond and vertical flow constructed wetland wastewater treatment system of rural sewage treatment showed that the TN removal efficiency was $75.60 \%$, the removal rate slightly lower than the system. As can be seen from Fig. 3-3 and Fig. 3-4, the trends of $\mathrm{NH}_{4}{ }^{+}-\mathrm{N}$ and $\mathrm{TN}$ during the whole monitoring period are very similar, this is consistent with the study by Liu [21], which is related to the main component of $\mathrm{TN}$ is $\mathrm{NH}_{4}{ }^{+}-\mathrm{N}$.

Adsorption and retention of substrates in constructed wetland are the main ways to remove phosphorus [22], and different substrates show different adsorption characteristics and removal effects. As can be seen from Fig. 3-5, the influent TP concentration fluctuated in a wide range $(1.82 \mathrm{mg} / \mathrm{L} \sim 6.98 \mathrm{mg} / \mathrm{L})$ with no obvious change rule. The influent concentrations at the 22nd and 39th days reached the lowest and the highest, respectively. The original system (a) and the comparison system (b) effluent $\mathrm{TN}$ average concentrations reached $1.66 \mathrm{mg} / \mathrm{L}$ and $1.09 \mathrm{mg} / \mathrm{L}$, all maintained a good overall removal effect, the original system (a) and the comparison system (b) of TN removal efficiency reached $61.75 \%$ and $75.26 \%$, respectively, which are better than that of Asuman [23] using slag and sand as substrates in wetland system. It can be seen that the optimal configuration of a variety of substrates is better for the removal of phosphorus.

\subsection{Study on the improvement of removal efficiency by the optimized configuration of substrates at different influent concentrations}

The original system (a) and the comparison system (b) of the new biological filter bed and subsurface-flow constructed wetland coupling process are both equipped with self-ventilated pipe network system, the only difference is the substrate selection and configuration. Therefore, it is necessary to study the effect of two sets of coupling systems on the removal of pollutants from the aspects of the selection and layout of substrates.

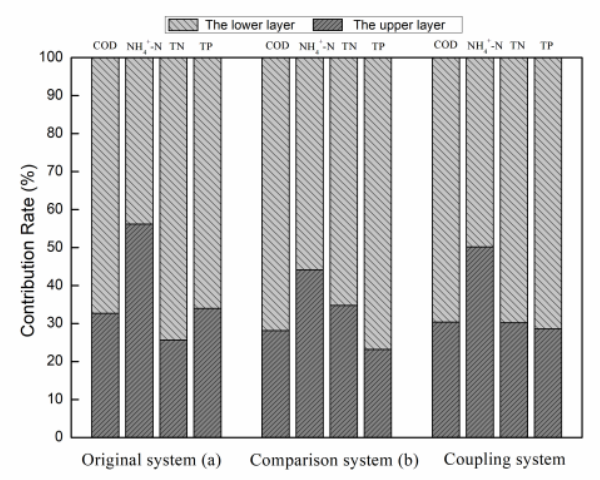

Fig.3-3. Contribution rates of removal of $\mathrm{CODCr}_{\mathrm{C}} 、 \mathrm{NH}_{4}{ }^{+}-\mathrm{N} 、 \mathrm{TN}$ and TP by lower and upper layer of different coupling systems at low influent concentration.

As a whole that can be seen from Fig.3-3, the contribution rate of the biological filter bed and the subsurface-flow constructed wetland in low influent concentration is $30.40 \%$ and $69.60 \%$ respectively in the removal of $\mathrm{COD}_{\mathrm{Cr}}$ by each unit of the pilot coupling system. In the removal of $\mathrm{NH}_{4}{ }^{+}-\mathrm{N}$ from each unit, the contribution rate of the biological filter bed and the subsurface-flow constructed wetland is $50.15 \%$ and $49.85 \%$, respectively. The contribution rates of removing $\mathrm{TN}$ is $30.22 \%$ and $69.78 \%$, respectively, while to TP the rate is $28.58 \%$ and $71.42 \%$, respectively.

Table 3-1 Removal effects of the new biological filter bed and subsurface-flow constructed wetland coupling system when treating low influent concentration wastewater

\begin{tabular}{cccc}
\hline $\begin{array}{c}\text { Water } \\
\text { quality } \\
\text { index }\end{array}$ & $\begin{array}{c}\text { The original } \\
\text { system (a) } \\
\text { removal rate }(\%)\end{array}$ & $\begin{array}{c}\text { The comparison } \\
\text { system (b) } \\
\text { removal rate }(\%)\end{array}$ & $\begin{array}{c}\text { Removal rate } \\
\text { increase }(\%)\end{array}$ \\
\hline CODCr & 63.10 & 74.10 & 11.00
\end{tabular}




$\begin{array}{cccc}\mathrm{NH}_{4}{ }^{+}-\mathrm{N} & 82.59 & 94.14 & 11.55 \\ \mathrm{TN} & 70.88 & 73.57 & 2.69 \\ \mathrm{TP} & 61.44 & 69.53 & 8.09\end{array}$

Table 3-1 lists the removal effects of the new biological filter bed and subsurface-flow constructed wetland coupling system when treating low influent concentration wastewater, and increase extent is also calculated. The comparison system (b) has significantly improved the main water quality index reduction than that of the original system (a), and the main water quality index is increased by $11.00 \%, 11.55 \%, 2.69 \%$ and $8.09 \%$ respectively when compared with the original system (a).

Table 3-2 Removal effects of the new biological filter bed and subsurface-flow constructed wetland coupling system when treating high influent concentration wastewater

\begin{tabular}{cccc}
$\begin{array}{c}\text { Water } \\
\text { qualit } \\
\begin{array}{c}\text { y } \\
\text { index }\end{array}\end{array}$ & $\begin{array}{c}\text { The original } \\
\text { system (a) } \\
\text { removal rate } \\
(\%)\end{array}$ & $\begin{array}{c}\text { The } \\
\text { comparison } \\
\text { system }(\mathrm{b}) \\
\text { removal rate } \\
(\%)\end{array}$ & $\begin{array}{c}\text { Removal } \\
\text { rate } \\
\text { increase } \\
(\%)\end{array}$ \\
\hline $\begin{array}{c}\mathrm{COD}_{\mathrm{C}} \\
\mathrm{r}\end{array}$ & 77.10 & 81.30 & 4.20 \\
$\begin{array}{c}\mathrm{NH}_{4}^{+}- \\
\mathrm{N}\end{array}$ & 81.08 & 90.28 & 9.20 \\
$\mathrm{TN}$ & 80.91 & 88.57 & 7.66 \\
$\mathrm{TP}$ & 61.75 & 75.36 & 13.61 \\
\hline
\end{tabular}

As can be seen from Table 3-2, the comparison system (b) has a significant increase in the concentration reduction of the main water quality index than the original system (a), The removal rates of $\mathrm{COD}, \mathrm{NH}_{4}{ }^{+}-\mathrm{N}$,
$\mathrm{TN}$ and TP in the comparison system (b) were $4.20 \%$, $9.20 \%, 7.66 \%$ and $13.61 \%$ higher than that of the original system (a) respectively. Thus, different substrates and configuration have a significant impact on the removal efficiency of the new biological filter bed and subsurface-flow constructed wetland coupling system, and the most obvious improvement for phosphorus removal efficiency. Different substrates have different adsorption characteristics and microbial adhesion properties, thus affecting the sewage treatment effect. Xu [24] selected four kinds of substrates to study their microbial activity changes and their effects on nitrogen removal, the results showed that the order of the microbial activity was sand/soil/peat mixture $>$ soil $>$ soil/sand mixture $>$ sand. Gu [25] studied the characteristics of microbial attachment to different substrates, it was found that there were $709,777,583$ and 568 species of bacterial colonies belonging to volcanic rocks, coke, zeolite and ceramsite, respectively, and the main microbial types and dominant species of different substrates were also different. Studies have shown that a variety of substrates combinations can improve the decontamination effect of wetlands. The types, physicochemical properties and disposition of substrates in constructed wetlands affect the growth of plants, and also affect the microbial activity in plant rhizosphere, ultimately affect the purification ability of constructed wetlands [11].

To sum up, it is easy to come to a conclusion that the comparison system (b) has higher removal rate in treating high influent concentration wastewater than treating low concentration case by the original system (a).

\subsection{Effect of temperature on the coupling system treatment effect at low and high influent concentrations}



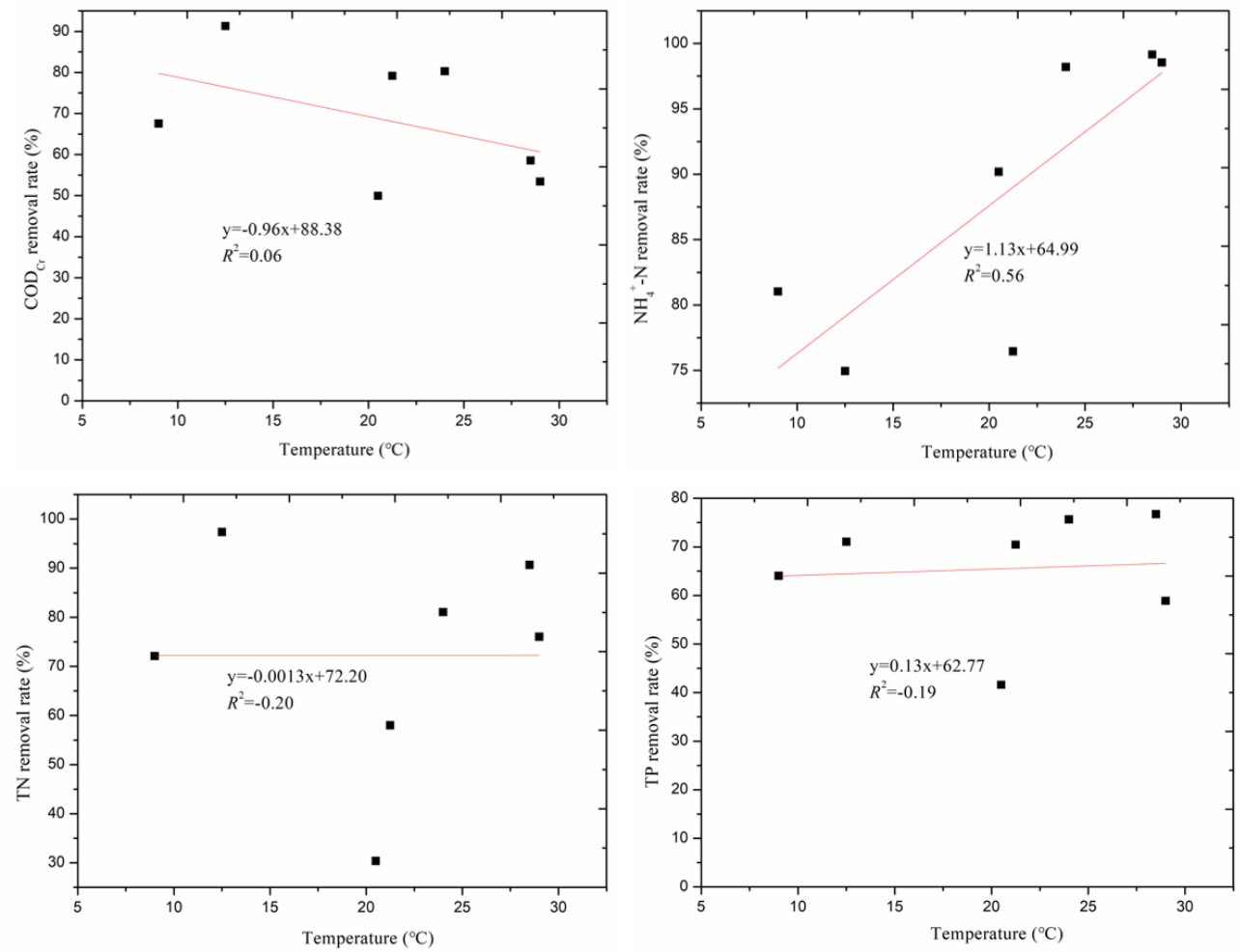

Fig.3-4 The impact on removal of main water index of coupling system by temperature at low influent concentration.

Fig.3-4 is a fitting chart of the effect of temperature on removal of main water quality index by a pilot coupling system treating low influent concentration wastewater. It can be seen that temperature has a negative correlation with the removal of $\mathrm{COD}_{\mathrm{Cr}}$ from the coupling system. Meanwhile, the temperature has a significant positive correlation with the removal of $\mathrm{NH}_{4}{ }^{+}-\mathrm{N}$ by the coupling system, which is positively correlated with other researchers' conclusions [26]. In addition, it is also found from Fig.3-4 that the effect of temperature on the removal of TN and TP is not obvious.
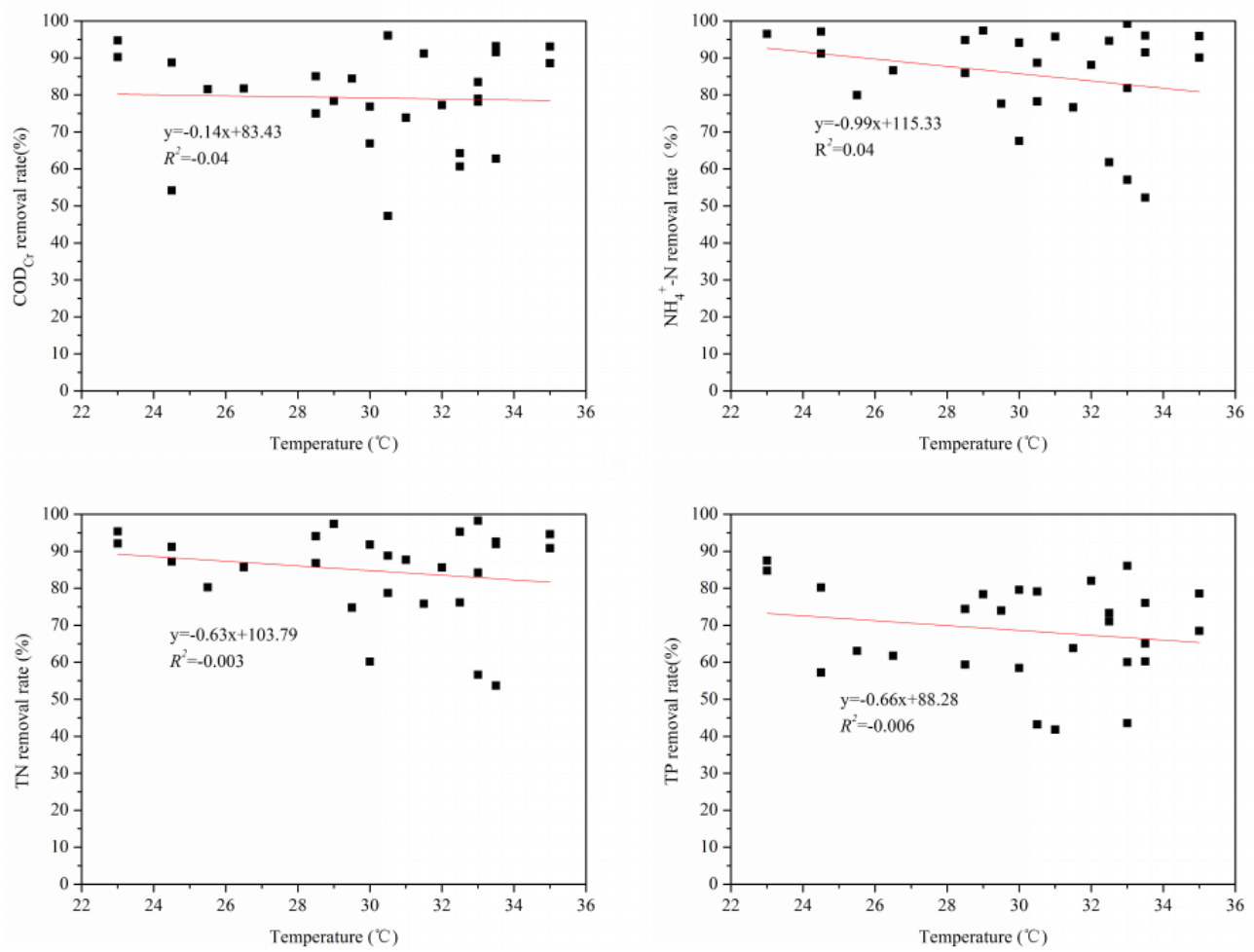

Fig.3-5. The impact on removal of main water index of coupling system by temperature at high influent concentration. 
Fig.3-5 is a correlation fit plot of the effect of temperature on the operating performance of coupled system as a whole. It can be seen from Fig.3-5 that the temperature has a negative correlation with the removal of $\mathrm{COD}_{\mathrm{Cr}}$ from the coupled system; Meanwhile, it is consistent with the conclusions of other scholars $[27,28]$. Some studies $[29,30]$ show that temperature has little effect on $\mathrm{COD}_{\mathrm{Cr}}$ removal rate in composite constructed wetlands, which is consistent with the results of this system $\left(R^{2}=-0.04\right)$. As the sampling time in the period of June to September, the temperature fluctuations in the $23 \sim 35^{\circ} \mathrm{C}$, it is a suitable temperature for nitrification and denitrification activities of micro-organisms [31], in addition, the influent concentration fluctuates greatly, and it may be difficult to show the actual fitting effect of $\mathrm{NH}_{4}{ }^{+}-\mathrm{N}$, TN removal rate and temperature. When the temperature is decreased, the dissolved oxygen (DO) concentration in the wetland will generally decrease, affecting the redox reaction and TP removal rate, however, the coupling system has the function of self-ventilation to ensure the amount of DO in the system, so the fitting degree of the removal rate and temperature is low $\left(R^{2}=-0.006\right)$, less affected by the outside temperature.

\section{Summary}

Based on the self-ventilated pipe network biological filter bed and subsurface-flow constructed wetland coupling system pilot project construction and its treatment of domestic sewage research draw the following conclusions:

1) The comparison system (b) had better removal rates than that of the original system (a), and the removal rate when treating low influent concentration was $74.10 \%, 94.14 \%, 73.57 \%$ and $69.53 \%$ for $\mathrm{COD}_{\mathrm{Cr}}$, $\mathrm{NH}_{4}{ }^{+}-\mathrm{N}, \mathrm{TN}$ and TP, respectively. The removal of the above main water indexes of the comparison system (b) promoted by $11.00 \%, 11.55 \%, 2.69 \%$ and $8.09 \%$ respectively in low influent concentration.

2) The influent concentration fluctuates greatly in the coupling system. The concentrations of $\mathrm{COD}_{\mathrm{Cr}}, \mathrm{NH}_{4}{ }^{+}-\mathrm{N}$, $\mathrm{TN}$ and TP in the comparison system (b) were $20.22 \pm$ $13.37 \mathrm{mg} / \mathrm{L}, 2.70 \pm 2.49 \mathrm{mg} / \mathrm{L}, 4.40 \pm 3.05 \mathrm{mg} / \mathrm{L}$ and $1.09 \pm 0.62 \mathrm{mg} / \mathrm{L}$. The removal of the above main water indexes of the comparison system (b) promoted by $4.20 \%, 9.20 \%, 7.66 \%$ and $13.61 \%$ respectively in high influent concentration. The optimal configuration of different substrates is more conducive to the degradation and removal of pollutants.

3) The optimized configuration of various kinds of substrates was significant and was more beneficial to the degradation and removal of pollutants. The adsorption and interception function of substrates in the constructed wetland was the main way of phosphorus removal. The function of self-ventilation ensured the amount of DO in the coupling system, making the phosphorus removal was less affected comparing to structure of traditional wetland.

\section{Acknowledgements}

This research was supported by Zhejiang Provincial Natural Science Foundation of China under Grant No.LY18E080005, the Major Science and Technology Program for Water Pollution Control and Treatment of China $12^{\text {th }}$ Five-Year Plan under Grant No.2014ZX07101-012, and Scientific Research Institute of Zhejiang provincial science and technology department No.2018F10031.

\section{References}

1. Dixon A, Simon M, Burkitt T. Assessing the environmental impact of two options for small-scale wastewater treatment: comparing a reedbed and an aerated biological filter using a life cycle approach[J]. Ecological Engineering, 20, 297-308 (2003).

2. Selma C. Ayaz, Özgür Aktaş, Nur Findik, et al. Phosphorus removal and effect of adsorbent type in a constructed wetland system[J]. Desalination \& Water Treatment, 37, 152-159 (2012).

3. Ceng Lingfang. A brief comment on new methods of rural domestic sewage treatment in foreign countries[J]. China Rural Nater and Hydropower, 9, 30-31 (2001). (In Chinese)

4. Ham J H, Yoon C G, Jeon J H, et al. Feasibility of a constructed wetland and wastewater stabilisation pond system as a sewage reclamation system for agricultural reuse in a decentralised rural area[J]. Water Science \& Technology A Journal of the International Association on Water Pollution Research, 55, 503 (2007).

5. Ye Yaling, Lu Mengjiang. Downflow anaerobic biofilter combined with constructed wetland to treat domestic sewage in small towns[J]. Environmental Research and Monitoring, 1, 43-45 (2004). (In Chinese)

6. Suo Yanli, Pan Jing, Chen Yongqiang. Research on decentralized domestic sewage treatment by combined biological and ecological system[J]. Journal of Shenyang Normal University (Natural Science Edition, 25, 376-380 (2007). (In Chinese)

7. Wu Caibin, Xiang Sulin, Lu Xiuguo. Combined technology of biological contact oxidization and constructed wetland for processing rural domestic sewage[J]. Hubei Agricultural Sciences, 47, 44-46 (2008). (In Chinese)

8. Qiu Zhi, Hu Zhifeng, Kong Lingwei, Zhang Chi. Research on engineering application of laminated ecological filter bed in the treatment of domestic sewage $[\mathrm{J}]$. Environmental Pollution \& Control, 36, 43-45 (2014). (In Chinese)

9. Kong L.W., He F., Xia S.B., et al. Research on the application of the modified aquatic mat pond and integrated vertical-flow construction wetland coupling process based on luffa sponge for micro-polluted water treatment[J]. Desalination and Water Treatment, 76, 155-165 (2017). 
10. Vymazal J, Kröpfelová L. Multistage hybrid constructed wetland for enhanced removal of nitrogen $[J]$. Ecological Engineering, 84, 202-208 (2015).

11. Wan Jiajing, Wan Zhan, Li Jun, et al. Function of the Substracts in the constructed wetlands[J]. Environmental Protection Science, 35, 16-19 (2009). (In Chinese)

12. Travis M J, Weisbrod N, Gross A. Decentralized wetland-based treatment of oil-rich farm wastewater for reuse in an arid environment[J]. Ecological Engineering, 39, 81-89 (2012).

13. S.Ç. Ayaz, Ö. Aktaş, N. Fındık, et al. Effect of recirculation on nitrogen removal in a hybrid constructed wetland system[J]. Water Science \& Technology A Journal of the International Association on Water Pollution Research, 40, 1-5 (2012).

14. Foladori P, Ortigara A R, Ruaben J, et al. Influence of high organic loads during the summer period on the performance of hybrid constructed wetlands (VSSF + HSSF) treating domestic wastewater in the Alps region[J]. Water Science \& Technology A Journal of the International Association on Water Pollution Research, 65, 890 (2012).

15. Zapater-Pereyra M, Ilyas H, Lavrnic, S, et al. Evaluation of the performance and space requirement by three different hybrid constructed wetlands in a stack arrangement[J]. Ecological Engineering, 82, 290-300 (2015).

16. Zhang X, Inoue T, Kato K, et al. Performance of hybrid subsurface constructed wetland system for piggery wastewater treatment $[\mathrm{J}]$. Water Science \& Technology A Journal of the International Association on Water Pollution Research, 73, 13 (2016).

17. Zhang D Q, Gersberg $\mathrm{R}$ M, Tansoon K. Constructed wetlands in China[J]. Ecological Engineering, 35, 1367-1378 (2009).

18. Jamieson T S, Stratton G W. The use of aeration to enhance ammonia nitrogen removal in constructed wetlands[J]. Canadian Biosystems Engineering, 45, 9-14 (2003).

19. Chung A K C, Wu Y, Tam N F Y. Nitrogen and phosphate mass balance in a sub-surface flow constructed wetland for treating municipal wastewater $[\mathrm{J}]$. Ecological constructed wetland for treating municipal wastewater[J]. Ecological Engineering, 32, 81-89 (2008).

20. Chen Heping, Zhang Chen, Zhu Heping, et al. Treatment of rural domestic wastewater by anaerobic-contact oxidation and vertical flow man-made wetland[J]. Journal of Ningbo University (Natural Science \& Engineering Edition), 21, 568-570 (2008). (In Chinese)
21. Liu Shentan, Wang Guofang, Xie Xiangfeng, et al. Effect of matrix on denitrification efficiency and distribution of nitrifying and denitrifying bacteria in constructed wetlands[J]. Journal of Southeast University (Natural Science Edition), 41, 400-405 (2011). (In Chinese)

22. Vymazal J. Constructed wetlands for wastewater treatment in the Czech Republic[J]. Water Science \& Technology A Journal of the International Association on Water Pollution Research, 7, 1-14 (1996).

23. Ban M. Comparison of the treatment performances of blast furnace slag-based and gravel-based vertical flow wetlands operated identically for domestic wastewater treatment in Turkey[J]. Ecological Engineering, 24, 185-198 (2005).

24. Xu Defu, Xu Jianming, Li Yingxue.The Microbial Activity of the Substrates in Constructed Wetland and Its Effect on the Removal of Nitrogen from Wastewater[J]. Journal of Agro-Environment Science, 27, 753-757 (2008). (In Chinese)

25. Gu Yonggang, Jin Pengkang, Li Zhaoxin, et al. Effect of different substrates on the species formation in the water bodies supplemented by reclaimed water $[\mathrm{J}]$. Environmental Pollution \& Control, 39, 1122-1126 (2017). (In Chinese)

26. Kong Lingwei, He Feng, Xia Shibin, et al. Studies on construction and performance of the Qiantang River water diversion de-nitrification demonstration project[J]. Environmental Pollution \& Control, 36, 60-66 (2014). (In Chinese)

27. Shen Z, Zhou Y, Hu J, et al. Denitrification performance and microbial diversity in a packed-bed bioreactor using biodegradable polymer as carbon source and biofilm support[J]. Journal of Hazardous Materials, 8, 250-251 (2013).

28. Kong Lingwei, He Feng, Xia Shibin, et al. Studies on construction and performance of the Qiantang River water diversion de-nitrification demonstration project. Environmental Pollution \& Control, 36, 60-66 (2014). (In Chinese)

29. Mæhlum, T., Stålnacke, P. Removal efficiency of three old-climate constructed wetlands treating domestic wastewater: Effects of temperature, seasons, loading rates and input concentrations[J]. Water Science \& Technology, 40, 273-281 (1999).

30. Vanier S M, Dahab M F. Start-up performance of a subsurface-flow constructed wetland for domestic wastewater treatment[J]. Environmental Technology, 22, 587-596 (2001).

31. Vymazal J. Horizontal sub-surface flow and hybrid constructed wetlands systems for wastewater treatment[J]. Ecological Engineering, 25, 478-490 (2005). 